Acta Universitatis Sapientiae, Philologica, 8, 3 (2016) 61-83

DOI: 10.1515/ausp-2016-0032

\title{
Handling Old Transylvanian Apple Variety Names in Translation
}

\author{
Imola Katalin NAGY \\ Sapientia Hungarian University of Transylvania \\ Faculty of Technical and Human Sciences \\ Department of Applied Linguistics, Târgu-Mureş \\ nimolkat@gmail.com
}

\begin{abstract}
This paper is related to the problems of translating horticultural terms and names. We deal with the translation issues of botanical names in general, then we focus on some old apple varietal names (Pónyik, Batul, Tányéralma, etc.) and the way these names are treated in English/Romanian texts. We also present some aspects related to the historical background of name giving and pomology. Our aim is to identify the main tendencies of such names in scientific writings and other types of texts. Prior to the publication of the Cultivated Code in the 1950s, the situation of varietal names was rather ambiguous, and sometimes several varietal names were circulating for the very same fruit variety or cultivar. That is why today we still talk about synonymy and translation in the field of variety names despite the fact that the Code stipulates a preference for non-translation. We also attempt to analyse the etymological implications of the above mentioned apple variety names, as especially Pónyik and Batul are equally claimed by Hungarian and Romanian pomologists.
\end{abstract}

Keywords: apple variety, botanical taxonomy, Pónyik, Batul, traditional Transylvanian apple varieties, translation, synonymy, etymology

\section{Introduction}

In Europe, the $16^{\text {th }}-17^{\text {th }}$ centuries brought about a development in agricultural and horticultural activities. Yet, formal agricultural training or research was not available until 1796, when a special academy was founded in Hungary, in the town of Keszthely. Thus, the end of the $18^{\text {th }}$ century witnessed the emergence of the first educational institutions in Central Europe (Szarvas, a school founded by Sámuel Tessedik in 1780; the so-called Georgikon in Keszthely: an agricultural school with the name Kis mezógazdasági iskola started by the Nakó Kristófi family 
in Nagyszentmiklós in 1799), following the curriculum and the programmes used by Tessedik earlier (Balog et al. 2008: 13-16).

In what agricultural research is concerned in this Transylvanian milieu, we can say that in the $18^{\text {th }}$ century there were only handwritten advice books and calendars related to vineyard cultivation and wine production. However, in the $19^{\text {th }}$ century, the first modern research activities in the field sprang, important works appeared, such as $A$ szóloomúvelés és borokkal való bánás by József Naláczi and Ferenc Milotai (Enyed, 1830) or Gazdasági Katechézis (Kolozsvár, 1832). The periodical Erdélyi gazda was first published in Enyed in 1869 (Balog 2008: 27). Agricultural research and terminology started to be more and more standardized and stable in the $19^{\text {th }}$ century and more and more scientific works were published. As one of the most important components of horticulture is fruit growing or pomology, we will focus in this study upon some old apple varietal names ('Pónyik', 'Batul', 'Tányéralma', etc.) and the way these names are treated in English and Romanian texts. We will raise translation problems, semantic and etymological issues alike.

Translating specialized texts is a process of text taming, which involves the linguistic analysis of the text, but one should also consider the socio-cultural background. "In translating a technical text, everything depends on the translator's knowledge of the special characteristics of the text, on his cultural knowledge, especially on his knowledge of the technical domain the text belongs to. But as this task cannot be carried out by a translator who is not a technical specialist, the accuracy of the translation greatly depends on the collaboration with the specialist in the subject" (Croitoru 2004: 21). Mastering the terminology is an essential skill for a future and a practising horticulturist alike. "Without terminology, there is no professional communication and without professional communication there is no transfer of knowledge" (Zauberga 2005: 107). In specialized translations, the denotative meaning of terms (conceptual, lexical, or dictionary meaning) is of utmost importance. Problems may arise in the case of synonymic series. Hence, in the case of the Hungarian verb metszeni (Romanian a elaga), if one fails to use the proper term to prune, and uses another term from the synonymic series cut, carve, engrave, gouge, slit, section, prune (down), and not the last one which means removal of plant parts, the meaning of the sentence will be completely altered. Cutting and pruning of an apple tree are definitely two very different things, and replacing one term with another changes the meaning of the whole text. Another major problem with horticultural texts is related to the translation and/or handling of names of genera, families, and other taxa.

The process of giving names to plants dates back to the ancient Roman and Greek civilizations, whose terminology was later overtaken and transmitted by scientists from different European monasteries or universities. Today's binominal nomenclature was introduced by the famous $17^{\text {th }}$ century botanist from Sweden 
Linné (1707-1778), also known as Linnaeus. In his Species plantarum, Linné introduced the binominal nomenclature, i.e. he named each plant with two Latin words: the name of the genus and the name of the species. The Linnaean binominal taxonomy prescribes that all plants should be given a name made up of two words: genus name and species (in Latin or transliterated in Latin). The International Code of Botanical Nomenclature states that they should be italicized, the genus name with capital letters, the species name with lowercaseletters. The author's name follows the species name, usually abbreviated. When the author's name is put into parentheses, this is an indication of the fact that the species is now considered as belonging to a different genus, due to the contribution and description of another author. Specific or scientific names in horticulture consist of two words: the name of the genus followed by the specific epithet, i.e. the species name. Thus, both terms are usually written in italics: the name of the genus requires an initial capital letter, while the name of the species does not (e.g. Stevia rebaudiana).

Folk taxonomy, on the other hand, is a classification of objects, which uses common names (also called vernacular name, colloquial name, trivial name, country name, farmer's name): mézfü is the Hungarian vernacular name for Stevia rebaudiana, but it is also called sztévia (balm in English). Linnaeus himself published the Flora of Sweden, Flora Svecica (1745), where he recorded the Swedish common names, alongside with scientific names. Unlike botanical and cultivar names, common or vernacular names are not governed by international rules. However, it is recommended to be written in Roman type, with lowercase initial letters, except when the word is a geographical or a personal name. This applies also when the scientific name has become a common name and if the scientific name has turned into a plural noun: potato, camellia, Jersey lily, rhododendrons. "Many species have a plethora of common names of very local usage, even within a small country, and widespread plants have common names in many languages" (Alexander, 2007: 5). Many people use terms like rhododendron, chrysanthemum, or fuchsia as the common names for these large groups of plants, but, in fact, these are their scientific names that have passed into common usage. This demonstrates the great strength of scientific denominations.

The rules for naming plants are today published by the International Code of Botanical Nomenclature, the most recent edition being the International Code of Nomenclature for algae, fungi, and plants, also called the Melbourne Code, issued in 2012 and adopted by the Eighteenth International Botanical Congress Melbourne, Australia, July 2011. The Melbourne Code is an improved version of the previous Vienna Code (2005), the St. Louis Code (1999), and the Stockholm Code (1952).

In 1952, the Committee for the Nomenclature of Cultivated Plants of the International Botanical Congress and the International Horticultural Congress in 
London adopted the International Code of Nomenclature for Cultivated Plants. Sometimes known as the Cultivated Code, it was first published in 1953 and since then has been revised several times at irregular intervals. This Code formally introduced the term 'cultivar' to encompass all varieties or derivatives of wild plants which are raised under cultivation and its aim is to 'promote uniformity and fixity in the naming of agricultural, silvicultural and horticultural cultivars (varieties)'. In cultivation, variation within species or resulting from hybridization often needs to be recognized and named. Thus, we have the term cultivar (from cultivated variety) and given cultivar epithets. This cultivar epithet, when attached to the binomial genus name, forms the full cultivar name. The term cultivar epithet refers only to the final element of this complex name (the word or words enclosed in single quotation marks, never double quotation marks). Thus, the cultivar name consists of the genus name (e.g. Malva) and species epithet (e.g. moschata) followed by the cultivar epithet (e.g. 'Pink Perfection'): Malva moschata 'Pink Perfection'). Cultivar names are usually enclosed in single quotation marks or apostrophes and are never written in italics. They are never translated, rather left as such. "Cultivar epithets may not be translated into different languages. Where this has happened the translation is to be regarded as a trade designation. The transcription or transliteration of epithets is permitted, e.g. from Japanese to English (transcription) or from Russian to English (transliteration)" (Alexander 2007: 25). Transliteration and transcription of cultivar epithet is permitted, but generally cultivar names should be given and left in vernacular languages. When translation occurs, cultivar epithets are treated as trade designations (Gledhill 2002: 51).

\section{Hungarian varietal names in English and Romanian texts}

In this study, we attempt to shed light on the treatment of traditional Hungarian cultivar names, i.e. varietal names of apples traditionally grown in Transylvania. We wish to take a look at the way Hungarian apple variety names are treated in English and Romanian (con)texts. As the majority of the names we will look at are prior to the introduction of the term cultivar, hereinafter, we will use the term variety instead of/alternately with the term cultivar (as this latter started to be used only after the 1950s).

The Hungarian common noun alma comes from an old Turkish word (amlu, almu/elma, alma) (Dibuz 2014: 38). Ferenc Nagy-Tóth, in his Népi gyümölcsészet és szakszerú gyümölcstermesztés Erdélyben, states that "The settling of the Hungarians in the Carpathian Basin influenced the fruit production of the Hungarians especially due to the fact that they renounced the nomad life and adopted Christianity. The forests, the sloping valleys, and the catchments were used together for the production of fruit trees, and this was very benefic for 
their development, natural selection, and reproduction too. The names of the settlements prove the importance of this occupation. Many settlements wear the names of fruits and fruit trees... The clergy invited from abroad (later local people who attended school abroad) had a great impact on the development of the agriculture of a people who now had stable settlements. This was especially due to the cultivation of the gardens of the abbeys and churches. It is important the fact that we have written sources talking about grafting of wild trees, thus making them fructify." ${ }^{1}$ Among the most dedicated Hungarian pomologists we mention the names of János Lippay, Ferenc Entz, Máté Bereczki, József Budai, Raymund Rapaics, Magdolna Tóth, etc.

In the Hungarian National List of fruit and grape varieties, ${ }^{2}$ which is published every year, the names of cultivars are treated correctly, and left untranslated, even when the accompanying text is in English: 'Daru Sóvári', 'Jászvadóka', 'Kecskeméti vajalma', 'Kenézi piros', 'Nyári csíkos borízú', 'Nyári csíkos fúszeres', 'Pónyik', 'Sikulai', 'Simonffy piros', 'Téli piros pogácsa', 'Tombácz', 'Török Bálint', etc. In doctoral theses and scientific articles, the cultivar names are also left in vernacular. For instance:

I prepared a list on 1100 apple and pear denomination[s]. It includes 235 apples with 673 different variety name[s] and 189 pears with 427 different variety names. The below mentioned 30 apple variet[ies] were the most frequent, which are present in more region[s]. These are listed in descending sequence. 'Téli arany parmen', 'Jonathan', 'Batul', 'Nemes sóvári', 'Török Bálint', 'Bőralma', 'Pogácsa alma', 'Pónyik', 'Borízú’, 'Húsvéti rozmaring’, 'Fontos alma', 'Cigány', 'London pepin', 'Tányér alma', 'Citrom alma', 'Vaj alma’, 'Csörgő alma’, 'Leánycsecsû alma', 'Téli piros pogácsa', 'Szentiváni alma', 'Eper alma', 'Masánszky', 'Selyem alma’, ‘Édes alma', ‘Budai domokos’, 'Arany renet', 'Nyári piros', 'Sárga szépvirágú', 'Rétes alma', 'Tök alma' ${ }^{3}$

The same happens all over the scientific texts we have analysed: "Among them, cultivar 'Beregi sóvári' displayed a highly susceptible host response to inoculation. The local cultivars 'Cserepánya' and 'Zöld sóvári' were classified as moderately susceptible. The cultivars 'Batul', 'Alexander', 'Simonffy piros' were moderately resistant, whereas 'Pónyik alma', 'Sikulai' and 'Szemes alma' were highly resistant." // "With regard to the flowering duration, mention should be made of the protracted flowering of 'Zöld batul' and 'Beregi sóvári 2', which

1 Ferenc, Nagy-Tóth, Népi gyümölcsészet és szakszerü gyümölcstermesztés Erdélyben, downloaded from: eda.eme.ro/.../EME_MNTE2005_123-140_Nagy-Toth\%20Ferenc\% 20-...

http://www.nakvi.hu/app/tanya/

http://phd.lib.uni-corvinus.hu/555/2/Szani_Zsolt_ten.pdf

http://www.actahort.org/books/663/663_35.htm 
had a very long flowering period". ${ }^{5}$ Another illustrative example could be the following fragment: "'Batul' (synonym: 'Patul') is one of the most attractive and widespread of the old apple cultivars from Transylvania.... Several variants of 'Batul' are known in Transylvania: 'Zöld batul', 'Fehér batul', 'Szögletes batul', 'Mosolygós', or 'Piros batul', 'Bordás batul', 'Félig piros batul', 'Sárga batul', 'Édes batul', 'Tüzes batul', 'Nagy batul', 'Selyem batul'”. ${ }^{6}$

In another article written in English, the following cultivar names appear (in Hungarian):? 'Fekete tányér alma', 'Beregi Sóvári', 'Cygany' (local name). ${ }^{8}$ Another good example of respecting the norm of not translating cultivar names is the following fragment:

The collective name 'Sóvári' covers a whole group of cultivars, as a great number of forms are to be found. The best known of these are 'Nemes sóvári', 'Beregi sóvári' and 'Daru sóvári'. Other variants can be found in certain locations: 'Közönséges sóvári' (syn.: 'Sovari commun'), 'Csíkos sóvári' (syn.: 'Sovari pestrit'), 'Piros sóvári' (syn.: 'Sovari rosu'), 'Zöld sóvári', 'Téli sóvári' (Bereczki, 1877, 1884; Bordeianu et al., 1964). German pomologists (Oberdieck and Lucas, 1860) and the Austrian pomologist Stoll (1988) were introduced to 'Daru sóvári' (syn: 'Daru alma') by the Hungarian pomologist Máté Bereczki. ${ }^{9}$

One interesting aspect to be noted here is the presence of synonymy at the level of cultivar names: 'Batul' (synonym: 'Patul') and 'Közönséges sóvári' (syn.: 'Sovari commun'), 'Csíkos sóvári’ (syn.: 'Sovari pestrit'), 'Piros sóvári’ (syn.: 'Sovari rosu'), a situation one should not normally expect in the case of such strictly regulated taxonomies. The explanation is historical: some of the traditional cultivar or variety names from Transylvania (once part of the Hungarian kingdom and presently part of Romania) have developed, over time, two parallel forms, a Hungarian and a Romanian version as well. Sometimes the Romanian version is

5 Ildikó Király, Characterisation of apple cultivars from the Carpathian basin by means of pomological analysis and molecular marker analysis based on microsatellites. Downloaded from: http://phd.lib.uni-corvinus.hu/716/3/Kiraly_Ildiko_ten.pdf.

6 Ildikó KIRÁLY, Róbert REDECZKI, Éva ERDÉLYI, Magdolna TÓTH. 2012. Morphological and molecular (SSR) analysis of old apple cultivars. Not. Bot. Horti. Agrobo. 40(1): 269-275. Downloaded from: http://www.notulaebotanicae.ro/index.php/nbha/article/ viewFile/7682/6850.

7 Marta DZIUBIAK, Old apple cultivars in the botanical garden-center for biological diversity conservation of the Polish Academy of Sciences. Downloaded from: http://bomax.botany.pl/ pubs/data/article_pdf?id=1124.

8 Most probably referring to Cigányalma.

9 Ildikó KIRÁLY, Róbert REDECZKI, Éva ERDÉLYI, Magdolna TÓTH. 2012. Morphological and molecular (SSR) analysis of old apple cultivars. Not. Bot. Horti. Agrobo. 40(1): 269-275. Downloaded from: http://www.notulaebotanicae.ro/index.php/nbha/article/ viewFile/7682/6850. 
the simple translated form of the Hungarian name, some other times adaptation and/or transformation is used to create the Romanian name. ${ }^{10}$

In what the treatment of Hungarian apple names is concerned in Romanian texts, the situation is ambivalent, as many times translated or adapted forms are used instead of the authentic Hungarian word. For instance, the cultivar 'Sóvari' is used under the transcribed form Şovar. ${ }^{11}$ The other old Hungarian apple cultivar, 'Pónyik', is used in Romanian texts under two forms: Ponic ${ }^{12}$ and Poinic. ${ }^{13}$ Other old Hungarian names of apple cultivars have not been translated and are not really used in Romanian texts: 'Török Bálint alma', 'Tányér alma' (also known as 'Pogácsa alma'), 'Budai Domokos'.

Bordeianu et al., in their comprehensive volume published in 1964, make a thorough presentation of the apple varieties and cultivars that could be found on Romanian territory. Among these, an impressive number of varieties are Transylvanian. We have analysed these varieties in point of linguistic explanations and synonyms given. It is obvious that, as with the other sources, synonymy in pomology means mostly the translation and/or adaptation of a fruit name (in)to other languages. What should be remarked here is the fact that the authors provide, in some cases, an impressive number of synonyms, in four or five languages. Another surprising fact is that, in the case of old Transylvanian varieties, which certainly do have a Hungarian name, they do not provide this, as for instance with: 'Ouțe de Ardeal', (synonym 'Țâța fetei'), 'Unsuroase de Geoagiu', (synonyms 'Untoase', mere de unt, 'Prundarițe'), 'Şovari comun', 'Şovari pestriț', 'Şovari Roşu', (without any known synonyms), ${ }^{14}$ 'Talgere' (without any known

10 In Nagy 2013, we have noticed a certain amount of inconsistency in the treatment and translation of cultivar names, as it can be noticed: in the same article, the same cultivar is once referred to as 'Seres Olivier', some other time as 'Olivier de Serres'. 'Bartlett' and 'Vilmos' are two cultivar names sometimes used in separate columns in tables, some other times used together, one of the names being put in parenthesis. The reason is that the cultivar is internationally known as 'Bartlett', but the Hungarian specialist literature uses it alternately with its Hungarian version 'Vilmos' or 'Vilmoskörte'. The tendency of Hungarian to translate cultivar names may be the reason for this, a tendency that is prior to the issuing of The International Code of Nomenclature for Cultivated Plants.

11 http://www.traiverde.ro/uploads/fisiere_biblioteca/13/Brosura\%20soiuri\%20mere.pdf

12 http://www.mihaieminescutrust.ro/malancrav/

În Mălâncrav există o tradiție în cultivarea pomilor fructiferi, numele maghiar al satului, Almakerek, însemnând chiar "măr rotund". Livada a fost lucrată intensiv în timpul communist şi apoi lăsată în paragină. În anul 2002 MET a preluat livada şi a transformat-o pentru a primi certificare ecologică. Pe o suprafață de cca 100 hectare cresc soiuri vechi, tipice pentru această zonă din Ardeal: Patul, Poinic, Renet de Leizberg, Renet de Bauman, Frumos de Boscop, Parmen Auriu şi Gustav Durabil, soiuri foarte aromate de mere care dau gust deosebit sucului de mere de la Mălâncrav. Sucul este produs în fabrica din livadă şi este, în mod previzibil, fără aditivi, zahăr sau conservanți.

13 https://dexonline.ro/definitie/poinic

póinic adj. m. (reg.; în sintagma) măr poinic = varietate de măr cu fructe mari, de culoare verzuie-galbenă, zemoase.

sinonime nu se cunosc 
synonyms), 'Parişe roşii de Feleac' (without any known synonyms). It is obvious that 'Țâța fetei' is the same as 'Leánycsöcsú alma',15 'Unsuroase de Geoagiu' is 'Gyógyi alma'16; the common element in 'Şovari comun', 'Şovari pestriț', and 'Şovari Roşu' is a simple transcription of 'Sóvári'. ${ }^{17}$ We add that 'Talgere' must be the Romanian version of the old Hungarian apple varietal name 'Tányéralma' or 'Tánygyéralma' and 'Parişe roşii' is 'Piros Páris'. The variety names 'Sălcii de vară', 'Mere Rusmaline', 'Muşcătarnițe', where Bordeianu et al. admit no known synonyms, are most probably linked to the Hungarian names 'Fúz alma', 'Fúzfa alma', 'Rozmaring alma', and 'Muskotály alma', all these varieties being present, together with their names, quite early in Transylvanian pomological literature. We could not identify Romanian texts on pomology which mention the Romanian version of 'Tányéralma' or 'Tánygyéralma'. Based on comparing the morphological characteristics of 'Tányéralma'18 and 'Talgere'19 and taking into account the possible etymological relationship between the Romanian word talger and its etymon, the Hungarian tányér, ${ }^{20}$ we assume that 'Tányéralma' stands for 'Talgere'.

In the case of 'Roşii de Geoagiu', the following synonyms are listed: 'Gyogyer roter' (German), 'Gyógyi piros' (Hungarian). In the case of 'Roşu de Stettin', the Hungarian synonym is correctly given as 'Török Bálint'. In the case of 'Şiculane' (transcription and calque of 'Sikulai'), the synonyms are 'Sikulai alma', 'Szekely alma' (Hungarian), 'Sikula' (French), 'Sikulaerapfel', and 'Seklerapfel' (German).

15 Balázs Szikszai Fabricius in his Szójegyzék (1590) mentions it under the form Lean czeczü alma.

16 Mentioned by Máté Bereczki, 1877, vol. 2, 307.

17 Although in the case of Şovari Nobil the following synonyms are mentioned: Nemes Sovari alma, Noble de Şovar, and Edel Soverapfel.

18 See Bereczki.

19 See Bordeianu et alii.

20 https://dexonline.ro/definitie/talger

TÁLGER e n. 1) Farfurie mică, plată. 2) Instrument muzical de percuție format din două discuri de alamă care, uşor lovit unul de altul, produce sunete puternice. /cf. ung. tálgyr. Source: NODEX (2002).

tálger, -e, (taljer), s.f. - Farfurie din tablă sau din porțelan, din care se serveşte mâncarea; blid: „Farfuria e mai d'est'isă, talgerul e mai scufundos” (ALR 1971: 310); „Dulce caş / P-un talgeraş” (Papahagi 1925: 204). - Et. nec. (DER, DEX). Source: DRAM (2011).

tálger, talgere, (taljer), s.f. - (reg.) Farfurie din tablă sau din porțelan, din care se serveşte mâncarea; blid: „Farfuria e mai d'est'isă, talgerul e mai scufundos” (ALRRM 1971: 310); „Dulce caş / P-un talgeraş” (Papahagi, 1925: 204). - Et. nes., cf. magh. tálgyer (MDA); cf. taler „platou, tava" ( $<$ bg. taler, DEX; nsl. taljer < germ. Teller, Scriban, Şăineanu, Miklosich, Cihac, cf. DER). Source: DRAM 2015 (2015).

cf. Zaicz 2006

tányér [1395k.] Olasz jövevényszó, vö. olasz (északolasz nyelvjárási) taSr, tajîr, tayVr, taVra: '(fa) tányér, vágódeszka', olasz régi nyelvi tagliere ‘vágódeszka'. Az olasz szavak a latin taliare 'hasít, bevág’ igére vezethetők vissza. A magyarban végbement ly > ny hangváltozásra vö. a fekély és a harkály régi nyelvi, illetve nyelvjárási fekény, harkány alakváltozatait. A szó az itáliai ételkultúra révén terjedt el Európa több nyelvében is (vö. német Teller 'tányér'), több szomszédos nyelvbe pedig a magyar is közvetíthette (vö. horvát-szerb tanjir 'tányér'). 
The proper noun is also transcribed according to Romanian spelling rules in 'Budai Domokoş' (synonyms 'Budai Domokos' and 'Pomme de Dominique de Budai'). The same phenomenon of wrong spelling is found with 'Roze de Geoagiu' (synonyms 'Roşiuțe', 'Vărgate de Geoagiu', and the Hungarian 'Roze de Gyogy', 'Gyogyi csicos', instead of 'Gyógyi csíkos'). Transcription is found in the case of 'Cormoşe Vărgate de Mada' (synonyms 'Mere de Mada', 'Verzi de Mada', 'Pereşti', 'Reinette grise de Mada', 'Graurapfel de Mada', 'Madai kormos').

\section{Synonymy in pomology}

Synonymy in pomology mainly refers to the existence and usage of more names for the same variety. These alternative names may be in the same language or may belong to different languages. Thus, with fruit varietal names, synonymy basically refers to real synonymy but to translation or adaptation as well. Total transformation occurs more rarely.

In Máté Bereczki's four-volume work on pomology, synonyms are provided for old apple varieties from Transylvania: 'Török-Bálint alma' is also referred to as Rouge de Stettin, Rother Stettiner (translation), or Türkischer Weinling, Rostocker, Annaberger, líother Zwiebelapfol, Malerapfel, Rubiner, Rother Bietigheimer, Vineuse rouge d'hiver; Seigneur d'hiver (synonyms) (Berecki 1877: 1, 435); 'Sikulaí alma' is also called Pomme de Sikula, Sikulaer Apfel, Székely alma (Berecki 1877: 1, 365); 'Gyógyi alma' is also called Rose de Gyógy, Gyógyer (Berecki 1877: 2, 307); 'Marosszékí piros' appears under the name Marosszékí piros páris (Berecki 1877: 2, 299), and 'Ponyik alma' is mentioned as Poinik Apfel, Pojnik, and Pojenics (Berecki 1877: 2, 333). Many other very old Transylvanian apple varieties display synonymic series: 'Székely zöld alma' - Zöld jeges (Berecki 1877: 4, 281), 'Márkodi alma' - Márkodi nözsér (Berecki 1877: 3, 325), 'Mádai kormos' - Pomme grise de Máda, Gfrauerapfel von Mada, Zöld kormos, Kormos (Berecki 1877: 2, 235). It is obvious that Berecki uses the term synonym (hasonnév) to refer to two different phenomena: real synonymy between two words in the same language (e.g. 'Mádai kormos' - 'Zöld kormos', 'Sikulaí alma' - 'Székely alma') and the translation of apple variety names from one language into another (e.g. 'Mádai kormos' - 'Pomme grise de Máda', 'Sikulaí alma' - 'Sikulaer Apfel').

Which are the main name-giving strategies or, more precisely, what are these names made up of? In apple variety denomination practices, there are some tendencies of name-giving.

In the Middle Ages, denoting one of the central characteristics of the fruit, one that we are able to directly experience with our senses such as its colour, 
size and taste played the most significant role in the naming of fruit varieties. Later, with the increase in the number of names, the differentiation of fruit varieties and the development of the science of pomology, this name type lost its exclusive role, but this functional-semantic category continued to be present in the greatest proportion - between $50 \%$ and $70 \%$ - in name giving in all of the time periods examined. As regards the adjunct in names with several constituents, the three most frequent functional categories are the place of origin (sóvári/alma 'apple from Sóvár'), the colour (sár/szilva 'yellow plum') and the time of ripening (aratási/körte 'harvest pear'). [...] Only two-constituent names were coined by way of syntagmatic formation, while one-constituent names were created through morphemic formation, semantic coinage and borrowing. In the case of structural change and external name formation processes, it is always a "fruit name" which serves as the basis for the name. As regards loans and calques, we cannot disregard the impact language contact exerts on the formation of the fruit name system, which is due partly to the cohabitation of neighbouring peoples in the Carpathian Basin, partly to the introduction and spread of new varieties through trade, and partly to scientific language.

[...] The importance of loan translations in name coinage increased together with that of artificial naming: the first wave of such coinage taking place in the $16^{\text {th }}$, while the second in the $19^{\text {th }}$ century. The increase in the proportion of borrowed names within the name stock correlates with the periods of either the flourishing of fruit breeding or the enriching of the fruit stock with foreign cultivars, which took place in the period preceding the Turkish occupation, as well as in the $19^{\text {th }}$ century. The historical sources are not rich in names coined through structural change or popular etymology (bergamot $>$ pergament): examples for these can be found mainly in dialectal sources" (Pelczeder 2011: 4-5).

Among the most common denomination tendencies, Dibuy (2014: 47-49) mentions: reference to the place of creation (toponyms, e.g. 'Sóvári', 'Szamosközi alma'), reference to the name of the creator, reference to the name of historical personalities or pomologists (antroponyms, e.g. 'Bereczki Máté alma', 'Török Bálint alma'), reference to the morphological characteristics of the variety or cultivar (adjectives related to the size, colour, sugar, or vitamin content, size of seeds, taste ('Muskotály birs'), adjectives or nouns related to ripening or usage qualities (such as time of ripening, storage qualities, usage characteristics, overall quality features, e.g. 'Búzával érő alma', 'Boldog asszony almája', 'Sós körte', 'Császár körte'). In the name of fruit varieties, these nominal or adjectival structures may appear on their own or together (e.g. 'Fekete tányér alma', 'Téli piros pogácsa', 'Magyar kormos renet'). 
In the case of very old, traditional varieties, the most common denomination practices were the reference to the place of discovery or creation, reference to a person (creator, descriptor, or historical personality). In all these cases, the names contained a proper noun. One more specific feature of Hungarian name giving was the fact that Hungarian names were coined to varieties coming from abroad (e.g. an apple variety coming from France, 'Douenne', came to be known in Hungarian as 'Császár körte'). We believe that the situation is explained by the difficulty of using foreign words in a society which was not always very familiar with foreign languages. In fact, this happens even today in many parts of the world, when vernacular names are given to foreign cultivars, even if the regulations of the Cultivated Code state that authentic names should be used (today, 'Ujjfehértői fehér fürtös' is used in Germany as 'Ungarische Traubige' and in the USA as 'Balaton', 'Érdi bőtermő' is named in the USA 'Danube' (Dibuy 2014: 47-49).

It is perfectly understandable that with old, traditional varieties the authentic vernacular names were not the only ones in use, and several so-called synonyms (in fact, translations into other languages, calques, or adaptations) circulated. (Let us not forget that most of these names were used in the plurilingual world of the Austro-Hungarian Empire.) Sometimes even in Hungarian the very same autochthonous variety had two or more Hungarian names. For instance, 'Beregi sóvári' has also been called 'Szolivarszke beregivszke', 'Budai Domokos alma' had the synonyms 'Pomme de Dominique Budai' and 'Dominik Budai’ Apfel, 'Húsvéti rozmaring' was also called 'Toklyó alma', 'Honti alma', or 'Entz rozmaring', 'Jászvadóka' was also named 'Barátalma', 'Sikulai' also wore the names 'Pomme de Sikula', 'Sikulareapfel', 'Székely alma', 'Seklerapfel', 'Kárpátalja szépe', and 'Kraszunya Zakarpattya'21 (Tóth 2014: 171-235). The situation is similar with the oldest autochthonous varieties: for 'Batul' apple, Tóth mentions the following series of synonyms, or parallel names: 'Batur', 'Narancsalma', 'Üvegalma', 'Batullenapfel', 'Batullen', 'Patul', 'Pomme de Transylvanie' (Tóth 2014: 197). For 'Gyógyi alma', she mentions the forms 'Tojás alma', 'Gyogyer roter', 'Rouge de Geoagiu', 'Rosii de Geoagiu', for 'Marosszéki piros páris' the names 'Piros páris', 'Paris Apfel', 'Paris rouge', and 'Parişe rosii' are listed, and for 'Pónyik' Magdolna Tóth mentions the synonymic series 'Török mocskotár', 'Poinic', 'Poinikapfel', 'Pojenics' (Tóth 2014: 201).

Ferenc Nagy-Tóth, in his Régi magyar gyümölcsfajták (1998), reminds us of some of the oldest texts containing fruit variety names, namely Péter Méliusz Juhász’ Herbárium (1578) (containing two names: Bolondító alma and Leánczeczü alma) and Balázs Szikszai Fabricius' Szójegyzék (1590), which mentions 14 apple varieties in Latin and in Hungarian, almost all of them being still existing varieties

21 Note that the list of synonyms in Tóth and in Bordeianu et al. do not coincide exactly in most of the examples cited. 
in Transyilvania today: Eleve érő alma, (Szentivány), Telelő alma, Apró piros alma, Muskotal alma, Igen edes alma, Mohos alma, Kerekded alma, Lean czeczü alma, Magnélkül való alma, Sömörközött (Szamosközi?) alma, Hegyes alma, Puha alma, Bor ízú alma, Kemeny alma (Nagy-Tóth 1998: 17). Towards the end of the $16^{\text {th }}$ century, there were some 60 Hungarian apple varieties in the records.

János Lippay's Posoni kert (its first volume focusing on flowers, the second one on vegetable growing, and the third volume centred on fruit) is another rich source of apple variety names in Hungarian: Sz. Ivány alma, Más Sz. Ivány alma, Darás alma, Más vörös alma, Métet alma, Nyári és telelő, Posoni Perlinger, Funtos alma, Leány alma, Telelő almák, Paszanan alma, Boldog asszony almája, Muskatal alma, Páris alma, Szegletes alma, Zöld muskatal, Bonyaburuttya, Kormos alma, Mesinki alma, Majner alma, Szent Benedeki alma, Selyem alma or Posoni alma, Bószniai alma, Tót piros, Báling alma (Lippay 2002: 143-144). Out of these, the following are Transylvanian varieties: Más vörös alma, Funtos alma, Leány alma, Telelő almák, Muskatal alma, Páris alma, Zöld muskatal, Kormos alma, Mesinki alma, Majner alma, Selyem alma or Posoni alma, Bószniai alma, Báling alma (Nagy-Tóth 1998: 19). Towards the $16^{\text {th }}$ century, fruit growing in Transylvania receded, but a new revival came with the dawn of the $17^{\text {th }}$ century, when new varieties appeared: Csipke alma (1758), Edes alma (1779), Apro edes alma, Nyári edes alma, Teli edes alma (1796) (Nagy-Tóth 1998: 20). It was the time when the very first Romanian variety names appeared, first in a Latin-Romanian dictionary (out of the 17 names mentioned here, 7 names did not have a Latin equivalent and 8 names had been taken from Szikszai’s Szójegyzék from 1590 (Nagy-Tóth 1998: 20).

The very first fruit tree nursery from Transylvania was established in 1812 in Cluj by Pál Bodor, (after Samuel Tessedik had established one in 1779 in the town of Szarvas). Pál Bodor studied in Germany and Wienna and he published in 1812 a catalogue of fruit varieties, entitled Eladó válogatott gyümölts-fa oltványok lajstroma. In this catalogue, he listed some 34 varieties, including Transylvanian fruit varieties (amongst which the apple varieties 'Bors', 'Jeges', 'Sóvári', 'Pónyik', 'Páris', and 'Batul' under the name 'Téli narancs alma') (Nagy-Tóth 1998: 22). A lot of famous nurseries and orchards appeared all over Transylvania (Árokalja, Kraszna, Zilah, Vérvölgy, Zsibó, Abafája, Sárpatak, Torda, Algyógy, Csáka, Diód, Máda, Mindszent, Bányabükk, Segesvárszék, Brassó, Fogaras, Háromszék, and Kézdivásárhely (Nagy-Tóth 1998: 23).

It was common practice that the same varieties had more names, depending on the region as, for instance, 'Batul alma' was called 'Narancs alma' around the town of Enyed and 'Sáromberki alma' in and around Görgény (Nagy 1853 apud NagyTóth 1998: 23). The first scientific description of the traditional Transylvanian varieties 'Páris', 'Pónyik', and 'Batul' was carried out by Ferenc Nagy. In his articles in Erdélyi gazda, he also described other old Transylvanian apple varieties as well ('Szászpap', 'Szásztángyér', 'Mádai kormos', 'Magyar tángyér', 'Piros’ and 
‘Csíkos gyógyi’, 'Muntenesco’ or Havasi, 'Káposzta’, 'Bánffy Pál’, 'Hosszúszárú páris’, ‘Kurtaszárú Páris’, ‘Zöld Páris’, 'Fejér Páris’, 'Páris mássa’, 'Márkodi nőzsér’, 'Mosolygó alma') - the information provided by Nagy here being later reproduced in Máté Bereczki's four-volume work. 'Borízú alma' is the same as the variety called by Lippai 'Bálint-alma' and by Ferenc Entz 'Török Bálint', its German name being 'Weinling'. 'Batul' alma displays a large series of synonyms ('Narancs alma', 'Üveg alma', 'Batullenapfel', 'Pomme Batul', 'Pomme de Transylvanie'), whereas 'Pónyik alma' is also called 'Poinik', 'Pojenics', and 'Poinik Apfel'.

\section{Etymology revisited. The case of 'Pónyik alma'}

Ferencz Nagy published in 1873 (Erdélyi Gazda) ${ }^{22}$ a series of articles related to the problem of traditional apple varieties. He mentions an anecdote according to which the name 'Pónyik alma' comes from the name of the place it was first discovered in the second half of the 1800s (the Romanian toponym Poiana mica). The anecdote published by Nagy was overtaken later by Máté Berecki in his Gyümölcsészeti vázlatok (Arad, 1877, vol. 2, 333), and since then the word Poiana has frequently been presented as the etymon of Pónyik.

In the $15^{\text {th }}$ volume of Magyar Nagylexikon (Vizi 2002) under the heading Pónik we find that in today's Slovakia there is a village called Pónik (variants Poniky, Ponik, Poinic), not far from the town of Besztercebánya (today Banská Bystrica, a town famous in Hungarian literature). This village was first mentioned in the records in 1282, up to 1886, its name was Pójnik, and it became part of Slovakia only in 1919, prior to that moment being part of the Hungarian kingdom. Some authors say that it is possible that the variety in question might have taken its name from the name of this small village, as the variety was widespread all over the Carpathian Basin up to the moment when its area was restricted to Transylvania $\left(19^{\text {th }}\right.$ century); so, today researchers list it as a Transylvanian variety. What is more, Nagy Tóth (apud Tóth 2014: 201) speaks about several villages with this name in the Carpathian Basin.

'Pónyik alma' is an ancient Transylvanian apple variety, first mentioned in the Döbrentey Kódex (1508) and Érsekújvári Kódex (1530-1531): ha nemzettenek az ponika almaak (apud Nagy-Tóth 1998: 41). Other records can be found in the 1600s, and thus Nagy-Tóth (1998) excludes the possibility that it is a variety discovered in 1848 in a small clearing, that is, in a poiana mica. Ponyik, besides the name variants mentioned earlier, is also called Pónyicska, Pányika. ${ }^{23}$

22 Nagy Ferencz, Erd. gazd. 1873. évfolyam, 396, quoted by http://phd.lib.uni-corvinus.hu/555/1/ Szani_Zsolt.pdf - Zsolt Szani: Történelmi alma- és körtefajták a Kárpát-medencében a népi fajtaismeret és -használat tükrében. 
We have attempted to look for other mentioning of this apple variety, and we have identified - in Döbrentei Kódex $-^{24}$ other fragments, not referred to in prevoius studies, fragments in which the name occurs as panika alma: Erosseknek minden fegveri Te ket emloid • miként ket gimborio eg hastol • kiket oriznek liliomba mignem nap támad es arnekok el haiollanak Miként panika alma reme ek $\bullet$ Te tvgid attól meg válva • mi belol enezik • Men nek el mirranak hegere • es temiennek dombiara es zoll'ak en iegesemnek (Döbrentei Kódex 1508: 477/993) and Ki az mezobe • lakozionk az falvkba Reggel kell'unk az zolokbe : es lassuk ha az zolo virágozot • ha az virágok gomlot bomboznak Ha az panika almák vir agoztak Ot en neked adom en emloimet Mand ragorak mi kapunkon illatot attak En zeretom $m$ ind vy almakot es 00 almakot es $\bullet$ neked tartottam iegesemnek (Döbrentei Kódex 1508: 482/1003).

According to Bordeianu et al. (1964), Poinic has the synonyms Ponyik (French), Poinikapfel (German), Ponyik, Pojnik, Pónyik alma, and Pojenics (Hungarian). Bordeianu et al. also state that it is believed that its name comes from the place where it was first discovered, poiana mica. For the etimology of 'Pónyik', Tóth (2014: 201) also refers to the anecdote described in 1873 by Nagy, an anecdote according to which sometimes in the 1800s a priest would be given a basket of apples from a shepherd. The priest showed the interesting apple variety to specialists, who named it with the Romanian word Poinic, based on the fact that the shepherd picked the apple from a small forest lawn (in Romanian: poiana mica). Based on this story about the discovery of this apple variety, many specialists have accepted this etymological reasoning, which, we consider, is utterly false.

We sustain our opinion by providing several arguments in this sense. First and foremost, the name 'Pónyik alma' was mentioned far earlier in history: in the Döbrentey Kódex (1508), according to Tóth (2014: 201) and according to our findings, and in the Érsekújvári Kódex (1530-1531), according to Nagy-Tóth (Nagy-Tóth 1998: 41).

Thus, the variety was not discovered in the $19^{\text {th }}$ century, and hardly could one think that a variety in cultivation far earlier (and named panika or ponika alma in the $16^{\text {th }}$ century) came to be given a name (poinic) only around the mid 1800 s. An apple variety recorded and cultivated at least from the $16^{\text {th }}$ century onwards is not very likely to be rediscovered and renamed in the $19^{\text {th }}$. Secondly, according to denominational practices, apple and fruit varieties were given names based on proper nouns (name of a town, village, area, ${ }^{25}$ etc.), and not on such general phrases meaning an area in the forest.

One more argument against the Romanian etimology of the word 'Pónyik' relies on the phonological evolution of the Romanian word poiana once it has penetrated the Hungarian language (Transylvanian dialect). In Régi magyar

24 Döbrentei Kódex, 1508, downloaded from: http://mek.oszk.hu/07500/07589/pdf/dobrentei2.pdf.

In Romanian: termeni entopici. 
glosszárium, szótárak, szójegyzékek és glosszák egyesített szótára (1989: 577), we find a Hungarian text featuring the word we analyse, a text which shows the form under which the word poiana was borrowed and used in Hungarian: pl. polyáni (Waldwiesen), Az eoz aratast uegeztettem el, az poliani határon. What is more, in Albert Wass' outstanding novel, The witch of Funtinel, the word poján appears frequently. Thus, the Romanian word poiana was borrowed by Hungarians under the forms polyáni, poliani, poján, so it is highly improbable that the phrase poiana mica was contracted in the form ponic or poinic (the word poiana did not undergo, in any of the forms referred to above, the phenomenon of apocope, i.e. the reduction of the final segment of the word to give a morpheme like poi). Further research is needed to clear up where different versions (especially the earliest forms panika, ponika) appear and what they can be linked to.

\section{The etymology of 'Batul'}

This seemingly very stable varietal name has had numerous variants over time. The name 'Batul' is sometimes used in Hungarian as 'Batur' ${ }^{26}$ Ferenc Nagy-Tóth (1998) states that 'Batul' comes from the name of a medieval Hungarian abbey from Bihar County, Batúr (existing between 1003 and 1172, in the garden of which monks grew different apple varieties). 'Batul' has the synonyms 'Batur', 'Bator' (Nagy-Tóth 1998: 39). Its first descriptor, Nagy $(1862,1873)$ said it was first grown in Transylvania by the Saxons and it had other names such as 'Pojenics', 'Narancs alma', or 'Üveg alma'. Its name has also the form Batuly. ${ }^{27}$

It is interesting to note that the name 'Batul' is sometimes used in Romanian texts in the form of 'Batul'28 and sometimes it shows as 'Patul', ${ }^{29}$ highlighting the fact that the form 'Patul' is used as a perfect synonym of 'Batul'. The cultivar name

26 adatbank.transindex.ro/html/alcim_pdf8879.pdf, 253.

27 http://mek.oszk.hu/00000/00060/html/011/pc001125.html\#4.

28 https://dexonline.ro/lexem/batul/197280.

batúl, -ă, adj. - (bot.) Soi de măr nobil (Malus pumila); mere batule (Borza 1968: 105): „În anii de recoltă bună se exportă 200-300 de vagoane de mere de soiuri nobile (Ionatan, Batul etc.) în Cehoslovacia, Ungaria, Germania, Siria şi Palestina” (Demeter, Marin 1935: 87). - Et. nec. Source: DRAM (2011)

29 https://www.facebook.com/pinussiculus/posts/905812339449525 - Soiuri de mere: Florina, Golden Delicious, Idared, Jonathan, Starkminson, Jonagold, Pinova, Golden spur, Gloster, Rewena, Ponic, Patul, Clar alb, Auriu de Cluj, Parmen Auriu, Gustav Durabil, Frumos Galben (Belle fleur jaune), Budai Domokos, Vargate de Geoagiu, Renet de Champagne, Renet de Cassel, Aport (Marele Alexandru), London Pepping, Sivari Nobil, Rosu de vara, Dulce-amarui (Entz Rozmarin), Gravenstein, Wagner premia sau: http://santerra-natural.ro/blog/soiuri-de-mererustice-romanesti/ - Marul Patul.

Originar de pe Valea Muresului, il intalnim astazi mai cu seama in livezile din Transilvania. Este considerat cel mai bun soi autohton. De ce "patul"? Deoarece in trecut aceste mere erau pastrate in patulul de fan. 
'Batul' has also two etymological explanations: on the one hand, some authors identify a Romanian etymology (the word patul, ${ }^{30}$ in Hungarian boglyafenék, in English the bottom part of a haystack). In an article published in 1907, the name appears under the adjectival form patule. ${ }^{31}$ Vasile Arvinte in his Note etimologice argues for the Romanian origin of 'Batul'. ${ }^{32}$ Zsigmond Csoma and Márta Mészáros in their Éva almája, almatortája subscribe to the Romanian etimology; nevertheless, they mention the other etymological possibilities as well. Géza Fúzi in his A soproni vidék gyümölcseinek származása, nevük eredete also subscribes to this idea. Marton Gy. in an article (Eredményeink és feladataink a magyar nyelvet érú román nyelvi hatástanulmányozása terén, 1959: 32) quotes an article from 1912 signed by István Damian (Adatok a magyar-román kölcsönhatáshoz in Nyelvészeti Füzetek 67), in which he claims that the word batul (alma) is of Romanian origin. According to Bordeianu et alii (1964), 'Pătul' has the synonyms 'Pătul galben', 'Batul alma', 'Üvegalma', 'Narancs alma', 'Batullenapfel', 'Batullen', 'Pomme de Transylvanie', and 'Pomme Batul', it comes from Mures Valley, and its name means bottom of haystack.

30 https://dexonline.ro/definitie/patul - PĂTÚL, ${ }^{1}$ pătule, s. n. 1. Construcție cu pereții din şipci, din nuiele împletite etc., ridicată pe un postament la mică înălțime deasupra solului, care serveşte la păstrarea porumbului (în ştiuleți); p. gener. hambar pentru cereale. 2. (Pop.) Coteț (construit pe pari sau într-un copac) pentru păsările de curte; coteț pentru porumbei. 3. (Pop.) Culcuş improvizat din frunze, din paie, din fân etc., care serveşte pentru dormit; p. ext. pat rudimentar (şi mic). 4. Un fel de podeț aşezat pe pari la suprafața apei, de pe care se pescuieşte. 5. Pătuiac. 6. Platformă înaltă construită pe stâlpi sau în copaci, care serveşte ca loc de observație (pentru paznici, pentru vânători etc.). - Cf. lat. * p a t u b u l u m (= patibulum).

31 Bunul econom. revista pentru agricultura, industrie si comert, nr. 10. 1907, 3-4, Soiul pomilor nostrii.

In fruntea tuturor stau merele patule. Acestea să cultivă exclusiv numai la noi. Să presupune că ele sunt de origine pădurețe. E sigur că sunt foarte răbdurii. Merii pătuli cresc încet dar' trăesc sute de ani. Ei au crengele subțirele, dar' fiind vânjoasă nu să rup uşor. Să pot ținea mult timp, până la Crăciun, îngrijite bine chiar şi până la Paşti. Sunt cam 6 soiuri. Cele mai bune sunt unele verzi, cari sunt toarte gustoasă; apoi unele roşii în cantitate mai mare, altele numai cu pete roşii etc. Şi unele şi altele întrunesc calități minunate. - Merele acestea sunt căutate de-o parte pentru că pomii aceştia sunt foarte răbdurii, iar lucru de căpetenie e că poamele sunt foarte gustoasă. Să transpoartă în toate părțile, apoi sunt foarte prezentabile. Ele cresc numai în Ardeal. pp 3-4.

32 Arvinte Vasile, Note etimologice, 173, downloaded from: http://www.alil.ro/wp-content/ uploads/2012/08/vasile.pdf.

Asemenea erori supărătoare mai există în lucrarea lui Gheorghe Iordache. Astfel, pe aceeaşi pagină, 309, se spune că denumirea batule (pâtule, pătulale), dată unor soiuri de mere, ar veni din germ. Batullen/apfelj, Balullen/baum. În limba germană literară (Nhd.) nu este cunoscut un asemenea cuvînt. El există însă în dialectul german al saşilor transilvăneni. Dar, cum se arată foarte clar în SS"YVI, B, p. 418, s ăs. Baiullenappeal re ca etimon rom. piitule” Heubett zum Einlagern von Gerntise und Ohst., namentlich auch, der untere Boden von Heutristen, in den Wint.erăpfel zum Heifwerden eingelagert werden”, La origine, denumirea s-a referit la un soi de mere de iarnă care se coc abia după ee stau în timpul iernii într-un pătul de fîn.Acelaşi autor, în Trepp. Wb., p. 104, compară cuvîntul săsesc cu austr. Butellenapțe! (din Stiria) 'Name .einer feineren Aptelgattung', deşi, originea românească este neîndoielnică. 
According to other Romanian texts, 'Pătul' (with its local names 'Batul', 'Butul') is a variety originating from Mures Valley, and its name derives from the bottom of haystack. ${ }^{33}$ In a study by Alexandru Pele, entitled Cuvinte româneşti in maghiară,$^{34}$ the word batul is listed among the Hungarian words of Romanian origin, but its etymology is still considered uncertain.

It is significant to note that the comprehensive Dictionary of Romanian Language, DEX online provides a different etymon for the name of this Transylvanian apple cultivar, namely the German term Batullen[apfel], Batullen[baum]. This could be an acceptable etymological explanation, as Berecki (1877: 2/295) mentions that the variety was first cultivated in Transylvania in the territories inhabited by Saxons, and thus the term most probably has a German etymology. Berecki also provides some synonyms for the name 'Batul alma': Batulen; Piros batullen; Narancs alma; Üveg alma; Pomme de Transsylvanie. (One of the synonyms of 'Batul', provided by Bereczki, namely Narancs alma, refers to another apple variety as well, a variety originating from Germany. ${ }^{35}$ )

André Leroy, one of Europe's most famous pomologists, listed in the 1873 tome of his six-volume Dictionnaire de Pomologie (which began to be published in 1869) the apple variety 'Batul' under the name 'Pomme Batullen' (its first descriptors being Ferenc Nagy and Tivadar Belke). It could have led to misunderstandings that the country of origin Leroy mentioned was Transylvania, part of Austria (and not the Austro-Hungarian Empire („Cett espece fut gagnée dans la Transsylvanie [Autriche]...”), a fact which could have contributed to neglecting or forgetting about its Hungarian linkage (Tolnay 2014: 11-12).

Thus, in what the idea that the word batul comes from the Romanian patule is concerned, we must note that the most important dictionary of Romanian (Dicționarul explicativ al limbii române - DEX) treats the two words, batul and patul, as two separate entries, and therefore there is no connection between the two items. On the other hand, in denomination practices, they rarely use reference to the modality or place of storage (but the storage life of a variety is among the naming procedures). It is hard to believe that batul comes from patule, referring to the bottom of the haystack, the place where the fruit was covered with hay and kept over winter. No one has analysed whether batul might have originated from the Hungarian words (possibly of Slovak or Slavic origin) batul

33 Ungureanu, Dumitru-Ardelean, Laura, Soiuri de măr şi păr din zona Sibiel şi Fântânele, Editura Constant, 2014 downoaded from: http://www.traiverde.ro/uploads/fisiere_biblioteca/13/ Brosura\%20soiuri\%20mere.pdf.

34 https://cumpana.wordpress.com/2007/08/24/cuvinte-romanesti-in-maghiara-chin/2007 batul (bătul, măr bătul), ultimii termeni fiind considerați totuşi incerți.

35 Narancsalma, 2, 367 (Orange d’ Allemagne; Pomeranzenapfel). Származása. E kitűnő alma hazája Németország, különösen pedig Württemberg: Hasonnevei. Breitliug; Breitachor; Breitapfel stb. Leírói. Diel. Kernobstsorten. I. 239. M 6111 er-Scherrer, Illustr. Handb. der Obstk. IV. 97. Leroy, Dict. de pomol. IV. 515. 
or batyul and/or batyu, ${ }^{36}$ meaning to pack or to cover (i.e. store the apple in a packed or covered form).

\section{Conclusions}

We have decided to study apple variety names as we wish to explore this segment of the lexicon to further our knowledge about the world that surrounds us. Katalin Pelczéder highlights in her study The system and historical study of fruit names the fact that fruit names can be analysed linguistically, and this kind of approach may contribute to widen our perspective and knowledge about the surrounding reality:

Although the linguistic study of fruit names could make an important contribution to research on the Hungarian lexicon in several respects, a systemic processing of these vocabulary items has not been undertaken by researchers so far. Plant names have often been the focus of lexicological studies, but the names of fruit varieties belong to a lesser-explored group of the word stock. [...] A linguistic examination of fruit variety names can be classified among lexicological works, as such a study can, on the one hand, provide important information for research in cultural history and, on the other hand, the resulting corpus of words may also serve as a basis for studies conducted in different areas of linguistics (research in terminology, language history, etymology, onomastics and nomenclature, dialectology). ${ }^{37}$

We have presented a synthesis of the opinions about the two most famous apple varieties, 'Batul' and 'Pónyik', ${ }^{38}$ as they are equally disputed by Hungarians and Romanians alike (the situation echoes the cases of pálinka, adapted to the Romanian word pălincă and more recently kürtöskalács, a true Hungarian realia, untranslated into Romanian and still claimed to be a traditional Romanian bakery product ${ }^{39}$ ). In such disputed territories as Transylvania, it is not surprising that

36 http://mnytud.arts.klte.hu/szleng/tanulmanyok/mny-nyr/urhegyi_emilia1985.pdf batyul (batul)

Itt meg kell jegyezni, hogy ezzel az érveléssel még nincs tisztázva e szavak etimológiája, és a batuló melléknévi igenév alapján feltételezhetố egy magyar batul ige is (1. a batyu-nál mondottakat).

37 http://doktori.btk.elte.hu/lingv/pelczederkatalin/thesis.pdf.

38 Curiously enough, none of them is listed in Attila Szabó T. (ed.) 2000. Erdélyi Magyar Szótörténeti Tár, Akadémiai Kiadó, Budapest - Erdélyi Múzeum Egyesület, Kolozsvár.

39 See the recent disputes over the paternity of this product between Romanian authorities and Hungarians (the Ministry of Agriculture intends to register this product in the EU as a traditional Romanian product, which, in their view, was first recorded in 1784, linked to a Romanian woman who prepared it. In fact, according to Attila Szabó T. et al. (2000: 710-711), the name kürtöskalács was first used in written records earlier, in a 1723 letter sent by Countess Ferrati Lajosné Kálnoki Ágnes to Apor Péterné Kálnoki Borbála. The fact is that another, even 
words are borrowed and/or translated, adapted from one language into another, and the very special historical background of this region, once belonging to Hungary and today being part of Romania, may explain that 'Batul' and 'Pónyik' are listed by both countries among the oldest autochthonous apple varieties. Linguistics may also contribute to solving this controversy; nevertheless, historical and linguistic records must be examined and etymology must be considered.

We have concluded that the relationship between 'Pónyik' and poinic is a simple case of folk etimology and poinic is not the word from which pónyik comes from. DEX does not provide etymological information related to poinic, but the word was recorded early in Hungarian texts and codices. We have also concluded that the relationship between the Hungarian 'Batul' and the Romanian patule is a formal coincidence, as even DEX treats them as unrelated terms. Thus, the claim that the two words are of Romanian origin is uncertain and further studies are required. The Romanian correspondent of 'Tányéralma' is most probably ‘Talgere' (at least the morphological features and the semantics of the two varieties present striking similarities). All the apple variety names (Romanian and Hungarian alike) are spelled with capital initial letters in scientific writings (these names are treated as proper names and the recommendations of the Cultivated Code are observed), whereas in non-scientific texts and scientific writings written before the issuance of the Code varietal names are written in both variants: with capital letters and with lowercase initial letters. In what Romanian scientific and nonscientific texts on such varieties are concerned, we recommend authors to use instead of soi românesc (meaning Romanian variety or cultivar) the structure soi din România (which stands for variety or cultivar from Romania). This could be a good strategy to avoid distortions and it would take into account the fact that some of the fruit varieties from Transylvania have always been claimed as traditional Hungarian varieties (öshonos magyar fajták) - their names have been recorded in centuries old texts written in Hungarian, the international specialized literature (among which the National Fruit Collection from the UK, one of the most important fruit inventories and genetic data banks in the world) considers them and treats them as Hungarian varieties ${ }^{40}$ yet, due to the historical evolution

earlier name of this product was kürtösfánk, recorded in 1679 (Kürtös Fánk sütéshez való fa, Uzdiszentpéter, Bajoni János inv. 63). Further recordings of the word occured in 1806, 1807, and 1804. Among the related word recordings, there are: 1792 - Kürtös kalács forma, 1761 - Kürtös kalács formájú, 1761 - Kürtös kalács sütô, 1810, 1816, 1840, 1851. According to other sources, another name of the same product was - in early writings - dorong fánk, but we will deal with the topic in a forthcoming study.

40 http://www.nationalfruitcollection.org.uk/names.php

Batul: Preferred name is Batul-alma »Dessert apple. Malus domestica Borkh. Thought to have originated in the early 1800s from Transylvania (Romania). Fruits have crisp flesh with a sweet to subacid flavour. Synonyms: Batul, Batulin, Batullen, Batullenapfel, Brilliantovoe, Mela Batullen, Narancsalma, Patul, Patul galben, Pomme Batul, Pomme Batullen, Pomme de Transsylvanie, Pomme de Transylvania, Pomme de Transylvanie, Uvegalma. 
of Transylvania, Romanians tend to call them and treat them as autochthonous Romanian varieties.

\section{References}

Balog, Adalbert-Bálint, János-Kovács, Lóránt-Kentelky, Endre-Jakab, SámuelNyárádi, Imre-István-Thiesz, Rezső. 2008. Az erdélyi magyar agrároktatás múltja, jelene és jövője. Târgu-Mureş: Editura Nico.

Berecki, Máté. 1877. Gyümölcsészeti vázlatok. Arad.

Bordeianu, T. (ed.). 1964. Pomologia Republicii Populare Romîne, vol. II, Mărul, Bucureşti: Editura Academiei RPR.

Croitoru, Elena (ed.). 2004. English through translation. Interpretation and translation-oriented text analysis. Galați: Editura Fundației Universitare Dunărea de Jos, Galați.

Dibuz, Erzsébet. 2014. Magyar gyümölcsfajták elnevezésének története és gyakorlata. In: Soltész, Miklós (ed.), Magyar gyümölcsfajták. Budapest: Mezőgazda Kiadó. 35-63.

Nagy, Imola Katalin. 2013. The usage and translation of plant names. In: Munteanu, Sonia-Bretan, Bianca (eds), Diversitate culturală şi limbaje de specialitate, Casa Cărții de Ştiintă, Cluj. 119-129.

Nagy-Tóth, Ferenc. 1998. Régi magyar gyümölcsfajták. Kolozsvár: Erdélyi Múzeum-Egyesület Kiadó.

Lippay, János. 1664/2002. Posoni kert, kiben minden kerti munkák, rendelések, virágokkal, veteményekkel, fákkal, gyümölcsökkel és kerti csömötékkel való baimolódások: azoknak nemek, hasznok, bé-csinálások bövségessen magyar nyelven le-irattattanak ... Lippay János-által. Eredeti kiadása: Nagy-SzombatBécs: Acad Ny.; Cosmerovius Ny., 1664-1667, Repr. [kiad.]. Budapest: Pytheas Kiadó..

Soltész, Miklós (ed.). 2014. Magyar gyümölcsfajták, Budapest: Mezőgazda Kiadó. Szabó, T. Attila (ed.). 2000. Erdélyi Magyar Szótörténeti Tár, Akadémiai Kiadó, Budapest - Erdélyi Múzeum Egyesület, Kolozsvár.

Tóth, Magdolna. 2014. Almafajtáink. In: Soltész, Miklós (ed.), Magyar gyümölcsfajták. Budapest: Mezőgazda Kiadó. 171-235.

Ponyik: Preferred name is Ponyik alma ») Culinary apple. Malus domestica Borkh. Discovered in a wood in Also-Feher called Pojana-mik (Sic!), Hungary. Recorded in 1872. Fruits have firm, rather coarse, cream-tinged green flesh with a slightly sweet flavour. Synonyms: Pognik Apfel, Poinic, Poinik, Poinik-Apfel, Poinikapfel, Pojenics, Pojeniks, Pojnick, Pojnickapfel, Pojnik, Pojnik Apfel, Pojnik-Apfel, Ponyik, Ponyik-alma. 
Tolnay, Gábor (ed.). 2014. Bereczki Máté és Dörgó Dániel levelezése IV. Szolnok: Verseghy Ferenc Könyvtár és Múvelődési Központ Verseghy Ferenc Elektronikus Könyvtár.

Vizi, E. Szilveszer (ed.). 2002. Magyar Nagylexikon, 15. kötet. Budapest: Magyar Nagylexikon Kiadó.

Zaicz, Gábor (ed.). 2006. Etimológiai szótár. Magyar szavak és toldalékok eredete. Budapest: Tinta Kiadó.

Zauberga, Ieva. 2005. Handling terminology in translation. In: Krisztina, KárolyFóris, Ágota (eds), New trends in translation studies. Budapest: Akadémiai Kiadó.

XXX. 1989. Régi magyar glosszárium, szótárak, szójegyzékek és glosszák egyesített szótára. Budapest: Akadémiai Kiadó.

\section{Internet sources}

http://www.nationalfruitcollection.org.uk/names.php. Retrieved 10.04.2016.

Döbrentei Kódex, 1508, downloaded from: http://mek.oszk.hu/07500/07589/pdf/ dobrentei2.pdf. Retrieved on: 17.03.2016.

www.eletteregyesulet.hu/dokumentumok/kertedertedszorolap.pdf. Retrieved on: 10.04.2016.

www.rhs.org.uk. Retrieved on: 06.3.2012.

http://www.geog.ubc.ca/biodiversity/eflora/Introduction to PlantTaxonomy.html.

Retrieved on: 16.03.2012.

http://www.fuszerkert.hu/cikk/botanikai-novenynevek. Retrieved on: 06.03.2012. http://www.edurite.com/kbase/binominal-plant-names. Retrieved on: 10.02.2012. http://www.actahort.org/books/663/663_35.htm. Retrieved on: 10.04.2016.

https://dexonline.ro/lexem/batul/197280. Retrieved on: 10.04.2016.

https://dexonline.ro/definitie/talger. Retrieved on: 10.04.2016.

http://santerra-natural.ro/blog/soiuri-de-mere-rustice-romanesti/. Retrieved on: 10.04.2016.

https://dexonline.ro/definitie/poinic. Retrieved on: 10.04.2016.

http://www.mihaieminescutrust.ro/malancrav/. Retrieved on: 10.04.2016.

https://www.facebook.com/pinussiculus/posts/905812339449525. Retrieved on: 10.04.2016.

http://www.nakvi.hu/app/tanya/doc/szolo_gyumolcs_NF_2014.pdf. Retrieved on: 10.04.2016.

http://mnytud.arts.klte.hu/szleng/tanulmanyok/mny-nyr/urhegyi_emilia1985. pdf. Retrieved on: 14.04.2016.

Adattár. Fajismeret (Elnevezés, Felhasználás). Downloaded from: adatbank. transindex.ro/html/alcim_pdf8879.pdf. Retrieved on: 10.04.2016. 
Bunul econom. Revista pentru agricultura, industrie si comert, nr. 10. 1907, downloaded from: http://documente.bcucluj.ro/web/bibdigit/periodice/ bunuleconom/1907/BCUCLUJ_FP_450152_1907_008_0034_0035.pdf. Retrieved on: 10.04.2016.

Alexics, György. 1909. Almanevek. In: Magyar Nyelvốr. 1909. 17, downloaded from: real-j.mtak.hu/5998/1/MagyarNyelvor_1909.pdf. Retrieved on: 10.04.2016.

Csoma, Zsigmond-Mészáros, Márta. Éva almája, almatortája. In: Pénzes, Tiborc Szabolcs (ed.), Tanulmányok Petróczi Éva hatvanadik születésnapjára, Budapest, 2011, downloaded from: plone.iti.mta.hu/rec.iti/Members/szerk/ septempunctata/Septempunctata.pdf. Retrieved on: 10.04.2016.

Crinan, Alexander (ed.). 2007. Plant names. A guide for horticulturists, nurserymen, gardeners and students. Written by the Horticultural Taxonomy Group - Hortax. http://www.hortax.org.uk. Retrieved on: 08.03.2012.

Fúzi, Géza. 1956. A soproni vidék gyümölcseinek származása, nevük eredete. In: Soproni Szemle X(1): 18. Retrieved on: 10.04.2016.

Marton, Gy. 1959. Eredményeink és feladataink a magyar nyelvet ért román nyelvi hatás tanulmányozása terén. In: Studia Unversitatis Babeş-Bolyai, Seria Philologia 32. Downloaded from: documente.bcucluj.ro/.../1959...Philologia/ BCUCLUJ_FP_491165_1959... Retrieved on: 10.04.2016.

Nagy-Tóth, Ferenc. Népi gyümölcsészet és szakszerú gyümölcstermesztés Erdélyben. Downloaded from: eda.eme.ro/.../EME_MNTE2005_123-140_NagyToth\%20Ferenc\% 20-... Retrieved on: 10.04.2016.

Pelczéder, Katalin. 2011. The system and historical study of fruit names. Downloaded from: http://doktori.btk.elte.hu/lingv/pelczederkatalin/thesis. pdf. Retrieved on: 10.04.2016.

Pele, Alexandru. 2007. Cuvinte româneşti în maghiară. Downloaded from: https:/cumpana.wordpress.com/2007/08/24/cuvinte-romanesti-in-maghiarachin/. Retrieved on: 10.04.2016.

Ungureanu, Dumitru-Ardelean, Laura. 2014. Soiuri de măr şi păr din zona Sibiel şi Fântânele. Editura Constant. Downloaded from: http://www.traiverde.ro/ uploads/fisiere_biblioteca/13/Brosura\%20soiuri\%20mere.pdf. Retrieved on: 10.04.2016.

Király, Ildikó-Redeczki, Róbert-Erdélyi, Éva-Tóth, Magdolna. 2012. Morphological and molecular (SSR) analysis of old apple cultivars. In: Not. Bot. Horti. Agrobo. 40(1): 269-275. Downloaded from: http://www. notulaebotanicae.ro/index.php/nbha/article/viewFile/7682/6850. Retrieved on: 10.04.2016.

Király, Ildikó. Characterisation of apple cultivars from the Carpathian basin by means of pomological analysis and molecular marker analysis based on 
microsatellites. Downloaded from: http://phd.lib.uni-corvinus.hu/716/3/ Kiraly_Ildiko_ten.pdf. Retrieved on: 10.04.2016.

Szani, Zsolt. Történelmi alma- és körtefajták a Kárpát-medencében a népi fajtaismeret és -használat tükrében. Downloaded from:

http://phd.lib.uni-corvinus.hu/555/2/Szani_Zsolt_ten.pdf. Retrieved on: 10.04.2016.

http://phd.lib.uni-corvinus.hu/555/1/Szani_Zsolt.pdf. Retrieved on: 10.04.2016.

Dziubiak, Marta. Old apple cultivars in the botanical garden-center for biological diversity conservation of the Polish Academy of Sciences. Downloaded from: http://bomax.botany.pl/pubs/data/article_pdf?id=1124. Retrieved on: 13.04.2016. 